Marquette University

e-Publications@Marquette

$10-1-2008$

Resonance Raman Spectroscopic Studies of Hydroperoxo Derivatives of Cobalt-substituted Myoglobin

Piotr J. Mak

Marquette University, piotr.mak@marquette.edu

James R. Kincaid

Marquette University, james.kincaid@marquette.edu

NOTICE: this is the author's version of a work that was accepted for publication in Journal of Inorganic Biochemistry. Changes resulting from the publishing process, such as peer review, editing, corrections, structural formatting, and other quality control mechanisms may not be reflected in this document. Changes may have been made to this work since it was submitted for publication. A definitive version was subsequently published in Journal of Inorganic Biochemistry, Vol. 102, No. 10 (October 2008): 1952-1957. DOI. (C) 2008 Elsevier. Used with permission. 


\title{
Resonance Raman Spectroscopic Studies of Hydroperoxo Derivatives of Cobalt-substituted Myoglobin
}

\author{
Piotr J. Mak \\ Department of Chemistry, Marquette University \\ Milwaukee, WI \\ James R. Kincaid \\ Department of Chemistry, Marquette University \\ Milwaukee, WI
}

\begin{abstract}
Recent progress in generating and stabilizing reactive heme protein enzymatic intermediates by cryoradiolytic reduction has prompted application of a range of spectroscopic approaches to effectively interrogate these species. The impressive potential of Resonance Raman spectroscopy for characterizing such samples has been recently demonstrated in a number of studies of peroxo- and hydroperoxo-intermediates. While it is anticipated that this approach can be productively applied to the wide range of heme proteins whose reaction cycles naturally involve these peroxo- and hydroperoxointermediates, one limitation that sometimes arises is the lack of enhancement of the key intraligand $\mathrm{v}(\mathrm{O}-\mathrm{O})$ stretching mode in the native systems. The present work was undertaken to explore the utility of cobalt substitution to enhance both the $\mathrm{v}(\mathrm{Co}-\mathrm{O})$ and $\mathrm{v}(\mathrm{O}-\mathrm{O})$ modes of the $\mathrm{CoOOH}$ fragments of hydroperoxo forms of heme proteins bearing a trans-axial histidine linkage. Thus, having recently completed RR studies of hydroperoxo myoglobin, attention is now turned to its cobalt-substituted analogue. Spectra are acquired for samples prepared with ${ }^{16} \mathrm{O}_{2}$ and ${ }^{18} \mathrm{O}_{2}$ to reveal the $\mathrm{v}(\mathrm{M}-\mathrm{O})$
\end{abstract}


and $\mathrm{v}(\mathrm{O}-\mathrm{O})$ modes, the latter indeed being observed only for the cobaltsubstituted proteins. In addition, spectra of samples prepared in deuterated solvents were also acquired, providing definitive evidence for the presence of the hydroperoxo- species.

\section{Introduction}

Structural characterization of reactive heme-oxygen species, including peroxo-and hydroperoxo- ferric forms, as well as the ferryl (Compound II) and ferryl $\Pi$-cationic (compound I) intermediates, is an important step in gaining useful insight into the precise catalytic mechanisms of various heme-containing enzymes [1-7]. While the resonance Raman (RR) technique has proven itself to be of immense value for probing many of these species [8-16], it has been only recently that this method has been successfully applied to interrogate hydroperoxo myoglobin as well as key intermediates in the enzymatic cycle of Cytochrome P450, the peroxo- and hydroperoxo- forms [1719]. These recent studies were inspired by pioneering work of several research groups showing that such heme protein intermediates can be efficiently generated and stabilized by radiolytic cryoreduction techniques [20-34].

Given these initial successes in acquiring RR spectra of these important species, it is anticipated that this approach can be productively applied to the wide range of heme proteins whose reaction cycles naturally involve these peroxo-hydroperoxo intermediates. However, while the studies of the cytochrome P450 intermediates, bearing a cysteine-thiolate as the trans-axial ligand, revealed effective enhancement of both the $\mathrm{v}(\mathrm{Fe}-\mathrm{O})$ and $\mathrm{v}(\mathrm{O}-\mathrm{O})$ modes [35-37], the acquired spectra of hydroperoxo-Mb exhibited a distinctive peak attributable to the $\mathrm{v}(\mathrm{Fe}-\mathrm{O})$ stretch of the $\mathrm{FeOOH}$ fragment, but no evidence for enhancement of the structurally sensitive intraligand $\mathrm{v}(\mathrm{O}-\mathrm{O})$ mode, a result that is consistent with the lack of enhancement generally seen for the dioxygen adducts of histidyl ligated heme proteins; to date there is only one known exception to this general trend, with both the $\mathrm{v}(\mathrm{Fe}-\mathrm{O})$ and $\mathrm{v}(\mathrm{O}-\mathrm{O})$ modes being seen only for a Chlamydomonas and Synechocystis hemoglobins [38].

Journal of Inorganic Biochemistry, Vol. 102, No. 10 (October 2008): pg. 1952-1957. DOI. This article is (C) Elsevier and permission has been granted for this version to appear in e-Publications@Marquette. Elsevier does not grant permission for this article to be further copied/distributed or hosted elsewhere without the express permission from Elsevier. 
The lack of enhancement of the $\mathrm{v}(\mathrm{O}-\mathrm{O})$ modes of dioxygen adducts of the native (iron-containing) heme proteins was overcome in many early RR studies by employing cobalt-substituted analogues, wherein the $\mathrm{v}(\mathrm{O}-\mathrm{O})$ of the $\mathrm{CoOO}$ fragments are quite efficiently enhanced via resonance with underlying charge-transfer transitions [39]. The present work was undertaken to explore the utility of cobalt substitution to enhance both the $\mathrm{v}(\mathrm{Co}-\mathrm{O})$ and $\mathrm{v}(\mathrm{O}-\mathrm{O})$ modes of the $\mathrm{CoOOH}$ fragments of hydroperoxo forms of heme proteins bearing a trans-axial histidine linkage. Specifically, having completed RR studies of hydroperoxo myoglobin $[17,18]$, attention is now turned to its cobalt-substituted analogue. In order to secure assignments, spectra are acquired for samples prepared with ${ }^{16} \mathrm{O}_{2}$ and ${ }^{18} \mathrm{O}_{2}$, comparison of which reveals modes associated with the $\mathrm{v}(\mathrm{M}-\mathrm{O})$ and $\mathrm{v}(\mathrm{O}-\mathrm{O})$ modes, the latter indeed now being observed here only for the cobaltsubstituted proteins. In addition, in seeking to distinguish between peroxo- and hydroperoxy- species, spectra of samples prepared in deuterated solvents were also acquired and compared to those obtained for samples prepared with natural abundance solvents, any shifts to lower frequencies observed for the deuterated samples being taken as evidence for the presence of the hydroperoxo- species. It is emphasized that while these cobalt-substituted proteins may reasonably be considered to adopt active site structures similar to those of the native proteins, comparable reactivity should not be assumed.

\section{Experimental}

\section{Materials}

The Co(III)-protoporphyrin IX was purchased from Frontier Scientific (Logan, UT) and used for preparation of cobalt analogues of horse heart myoglobin (Mb) (Sigma-Aldrich, Milwaukee, WI). The proteins purification and buffer exchanges were performed using BioGel P-6, AG 501-X8 (D) Resin (Bio-Rad Laboratories, Hercules, CA), Sephadex G-25 (Sigma-Aldrich, Milwaukee, WI) and CM-52 cellulose (Whatman, Fairfield, NJ).

Journal of Inorganic Biochemistry, Vol. 102, No. 10 (October 2008): pg. 1952-1957. DOI. This article is (C) Elsevier and permission has been granted for this version to appear in e-Publications@Marquette. Elsevier does not grant permission for this article to be further copied/distributed or hosted elsewhere without the express permission from Elsevier. 
NOT THE PUBLISHED VERSION; this is the author's final, peer-reviewed manuscript. The published version may be accessed by following the link in the citation at the bottom of the page.

\section{Protein Preparation}

The apoMb was prepared using the acid-acetone method [40] and insertion of reduced $\mathrm{Co}$ (II) was performed anaerobically according to previously published procedures [41]. Briefly, the 1.2 molar excess of reduced $\mathrm{Co}$ (II) protoheme ( $30 \%$ aqueous pyridine solution, $10 \%$ of apoMb volume) was added anaerobically to apoMb dissolved in 100 $\mathrm{mM}$ PB pH 7.0. The mixture was stirred under Ar gas for 5 minutes and then applied on Sephadex G-25 column equilibrated with degassed $10 \mathrm{mM}$ PB pH 6.0. The mixture of deoxy/oxy MbCo(II) protein was collected first and then purified on $\mathrm{CM}-52$ column equilibrated with 10 $\mathrm{mM}$ PB pH 6.0. The cobalt Mb was adsorbed on the ion exchanger and washed with the same buffer until the eluent was clear. The pure protein was eluted using $100 \mathrm{mM}$ PB pH 7.0. The protein was then saturated with oxygen and gave UV-VIS spectrum characteristic for Co(II)-oxy myoglobin (426 nm, $539 \mathrm{~nm}, 577 \mathrm{~nm}$ ). In order to make sure that protein didn't contain any traces of oxidized Co(III) the sample was deoxygenated using argon gas and the UV-Vis spectrum was collected. The absorption spectrum showed only deoxy form of Co(II) myoglobin ( $406 \mathrm{~nm}, 558 \mathrm{~nm}$ ) without any traces of oxidized $\mathrm{Co}$ (III) $\mathrm{Mb}$ [41]. The ${ }^{16} \mathrm{O}_{2}$ to ${ }^{18} \mathrm{O}_{2}$ substitution, as well as $\mathrm{H}_{2} \mathrm{O}$ to $\mathrm{D}_{2} \mathrm{O}$ exchange, were performed as previously reported [17-19]. The formation of oxy samples was confirmed using UV-Vis and resonance Raman spectroscopies $[39,41]$. The samples were in $100 \mathrm{mM}$ phosphate buffer, $\mathrm{pH} 8.3$ with $25 \%$ purified glycerol (by volume) (or glycerol- $d_{3}$, where applicable). The final concentration of protein was $0.30 \mathrm{mM}$ in heme. The samples were stored in NMR tubes (WG-5ECONOMY, Wilmad Glass) at $77 \mathrm{~K}$.

\section{Irradiation and Annealing Procedures}

The oxygenated samples immersed in liquid nitrogen were irradiated for 5 hours using the ${ }^{60} \mathrm{Co}$ source at Notre Dame Radiation Laboratory (Notre Dame University, IN) and were exposed to $0.97 \times$ $10.1 \mathrm{krad} / \mathrm{min}$. The irradiated samples were stored in liquid nitrogen. The cryoreduced samples were annealed at higher temperatures by quickly (around 1 second) transferring the irradiated sample into a solvent/liquid nitrogen bath at desired temperatures and immersing it for $1.5 \mathrm{~min}$, then quickly transferring back into liquid nitrogen. The

Journal of Inorganic Biochemistry, Vol. 102, No. 10 (October 2008): pg. 1952-1957. DOI. This article is (C Elsevier and permission has been granted for this version to appear in e-Publications@Marquette. Elsevier does not grant permission for this article to be further copied/distributed or hosted elsewhere without the express permission from Elsevier. 
outside walls of NMR tubes after annealing were usually covered by ice that formed during freezing the sample back in liquid nitrogen (the samples were not wiped with paper or cloth since that could warm up the surface of the tube from which the scattered light is collected); instead, the ice was gently scraped away from the tube under liquid nitrogen using a pre-cooled (in liquid nitrogen) spatula.

\section{Resonance Raman Measurements}

Resonance Raman spectra were obtained using a Spex 1269 spectrometer equipped with an Andor Newton EMCCD detector (Model DU971, Andor Technologies). Excitation at $415.4 \mathrm{~nm}$ from $\mathrm{Kr}^{+}$laser (Coherent Innova 100-K3) was used to measure RR spectra of the samples before and after irradiation and annealing. The RR spectra were collected using back scattering $\left(180^{\circ}\right)$ geometry, a cylindrical lens was used to form a line image [42] with $1.0 \mathrm{~mW}$ (or less) laser power on the sample. The frozen sample, contained in a $5 \mathrm{~mm}$ O.D. NMR tube, was positioned into a double-walled quartz low temperature cell filled with liquid nitrogen and fitted with an NMR spinner. The sample tubes were spun to avoid local heating. Resonance Raman spectra of the oxygenated forms of MbCo were taken at $77 \mathrm{~K}$ before irradiation to document complete oxygenation. The spectra were calibrated with fenchone and processed with Grams/32 AI software.

\section{Results}

In this current effort to extend the earlier study of cryoreduced oxy Mb $[17,18]$, samples of oxy CoMb and its cryoreduced product have been prepared and studied. For completeness, corresponding spectra of native oxyMb are also included here (Figure 1), noting that the earlier work was carried out at $\mathrm{pH} 7.0$, while the data obtained here for oxyCoMb and oxyMb are acquired at $\mathrm{pH}$ 8.3, a value matching that used in an earlier work on oxyCoMb [39]. In Figure 1 it is seen that a feature attributable to the $\mathrm{v}(\mathrm{Fe}-\mathrm{O})$ of the oxyMb sample is observed at $578 \mathrm{~cm}^{-1}$, a value that is slightly higher than the $572 \mathrm{~cm}^{-1}$ frequency observed at room temperature. As shown previously $[17,18]$, upon cryoreduction the $578 \mathrm{~cm}^{-1}$ feature virtually disappears and is replaced by a new feature seen at $617 \mathrm{~cm}^{-1}$ in trace $C$ that exhibits the $\sim 25 \mathrm{~cm}^{-1}{ }^{16} \mathrm{O} /{ }^{18} \mathrm{O}$ isotopic shift expected for the $\mathrm{v}(\mathrm{Fe}-\mathrm{O})$ 
mode of an Fe-O-O fragment. Furthermore, the observed $\sim 5 \mathrm{~cm}^{-1}$ downshifts observed for both the ${ }^{16} \mathrm{O}_{2}$ and ${ }^{18} \mathrm{O}_{2}$ samples in $\mathrm{D}_{2} \mathrm{O}$ solution as shown in Figure 1 , trace $D$, is most consistent with formulation of this species as a hydroperoxo derivative; i.e., Fe-O-OH(D).

$\mathrm{FeMb} \quad \lambda_{\mathrm{ex}}=415 \mathrm{~nm} \quad 77 \mathrm{~K}$

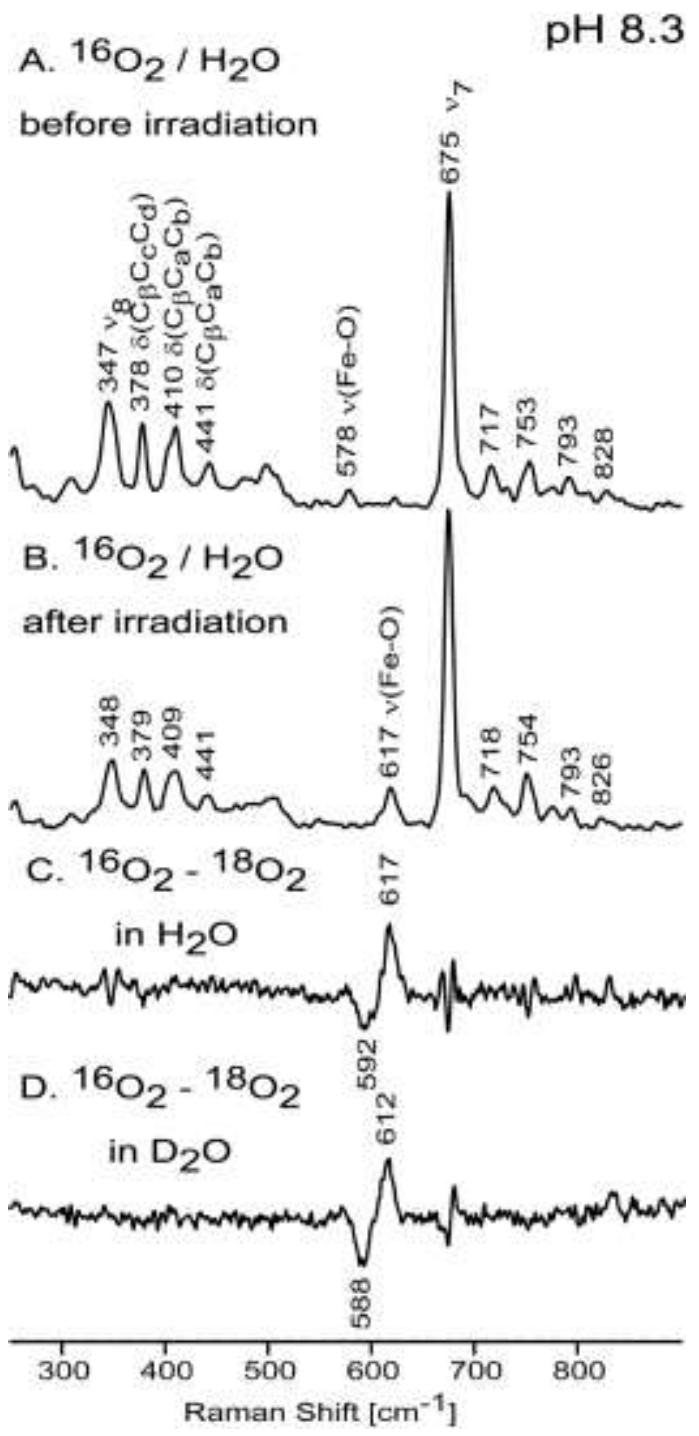

Figure 1 Low frequency resonance Raman spectra of native oxy myoglobin $\left({ }^{16} \mathrm{O}_{2} / \mathrm{H}_{2} \mathrm{O}\right)$ before $(A)$ and after $(B)$ irradiation. The two bottom traces show the difference spectra of ${ }^{16} \mathrm{O}_{2}-{ }^{18} \mathrm{O}_{2}$ in $\mathrm{H}_{2} \mathrm{O}$ (C) and ${ }^{16} \mathrm{O}_{2}-{ }^{18} \mathrm{O}_{2}$ in $\mathrm{D}_{2} \mathrm{O}$ buffer (D) of irradiated native oxyMb.

The RR spectra for oxy CoMb in both the low frequency and high frequency regions, obtained at $77 \mathrm{~K}$, are given in Figure 2, where it is 
seen that distinctive features are observed at 1136 and $1069 \mathrm{~cm}^{-1}$ for the $\mathrm{v}\left({ }^{16} \mathrm{O}-{ }^{16} \mathrm{O}\right)$ and $\mathrm{v}\left({ }^{18} \mathrm{O}-{ }^{18} \mathrm{O}\right)$ modes, the observed frequencies being slightly perturbed from their inherent values by a thoroughly documented and well understood vibrational coupling interaction between the $\mathrm{v}(\mathrm{O}-\mathrm{O})$ and internal modes of the trans-axial histidylimidazole ligand [39, 43, 44]. As has been documented in many previous studies $[12,45]$, no feature attributable to an enhanced $v(0-$ O) mode is observed for the oxyMb sample (data not shown). In the low frequency region a distinctive $\mathrm{v}(\mathrm{Co}-\mathrm{O})$ mode is observed at 549 $\mathrm{cm}^{-1}$, a value that (like the frozen oxyMb sample mentioned above) is also somewhat higher $\left(\sim 10 \mathrm{~cm}^{-1}\right)$ than that seen at room temperature in previous studies [17-19].This feature exhibits a nearly ideal ${ }^{16} \mathrm{O} /{ }^{18} \mathrm{O}$ isotopic shift and, as expected for a simple dioxygen adduct, no shift in buffers prepared with $\mathrm{D}_{2} \mathrm{O}$; there are no interfering coupled modes near the $\mathrm{v}(\mathrm{Co}-\mathrm{O})$ mode.

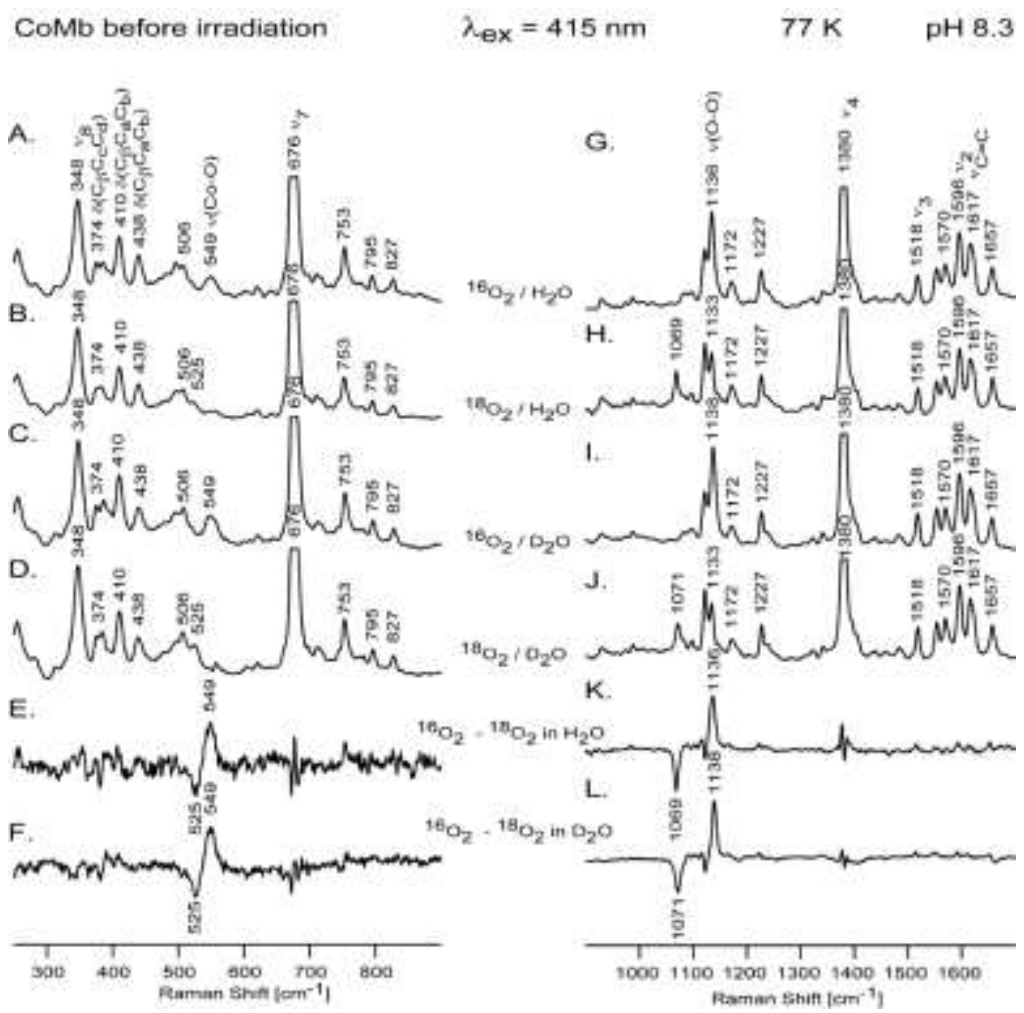

Figure 2 Low and high frequency resonance Raman spectra of ${ }^{16} \mathrm{O}_{2} / \mathrm{H}_{2} \mathrm{O}$, ${ }^{18} \mathrm{O}_{2} / \mathrm{H}_{2} \mathrm{O},{ }^{16} \mathrm{O}_{2} / \mathrm{D}_{2} \mathrm{O}$ and ${ }^{18} \mathrm{O}_{2} / \mathrm{D}_{2} \mathrm{O}$ samples of $\mathrm{Co}(\mathrm{II})$ myoglobin (MbCo) before irradiation and their difference spectra. 
Following irradiation of the oxygenated CoMb sample with the ${ }^{60} \mathrm{Co}$ source, the RR spectrum (Figure 3 ) shows a dramatic decrease in modes associated with the bound $\mathrm{Co}-\mathrm{O}-\mathrm{O}$ fragment, an observation that is made most evident by noting the decrease of the $1069\left(\mathrm{H}_{2} \mathrm{O}\right)$ and $1071\left(\mathrm{D}_{2} \mathrm{O}\right) \mathrm{cm}^{-1}$ features associated with the $\mathrm{v}\left({ }^{18} \mathrm{O}-{ }^{18} \mathrm{O}\right)$ modes in the high frequency region; e.g., comparing traces $\mathrm{K}$ and $\mathrm{L}$ in Figure 3 with those shown in Figure 2. This decrease in the intensities of the features associated with the bound dioxygen fragment is obviously consistent with cryoreduction of the dioxygen adduct to the peroxo- or hydroperoxo- form and this expectation is confirmed by the appearance of new modes in the low frequency region displayed in Figure 3. There, distinct difference patterns are seen with components being evident at $851 / 806 \mathrm{~cm}^{-1}$ and between 583 and $525 \mathrm{~cm}^{-1}$. The higher frequency $\left(851 / 806 \mathrm{~cm}^{-1}\right)$ pair, reasonably associated with the $\mathrm{v}(\mathrm{O}-\mathrm{O})$ mode of a peroxo- or hydroperoxo- fragment, exhibits a clear difference pattern yielding an extracted isotopic shift of $45 \mathrm{~cm}^{-1}$, in good agreement with theory for such a $\mathrm{v}(\mathrm{O}-\mathrm{O})$ mode. Furthermore, the $6 \mathrm{~cm}^{-1}$ downshifts observed in buffers prepared in $\mathrm{D}_{2} \mathrm{O}$ support the formulation of these derivatives as hydroperoxo species, as was the case with the native (iron-containing) myoglobin samples $[17,18]$.

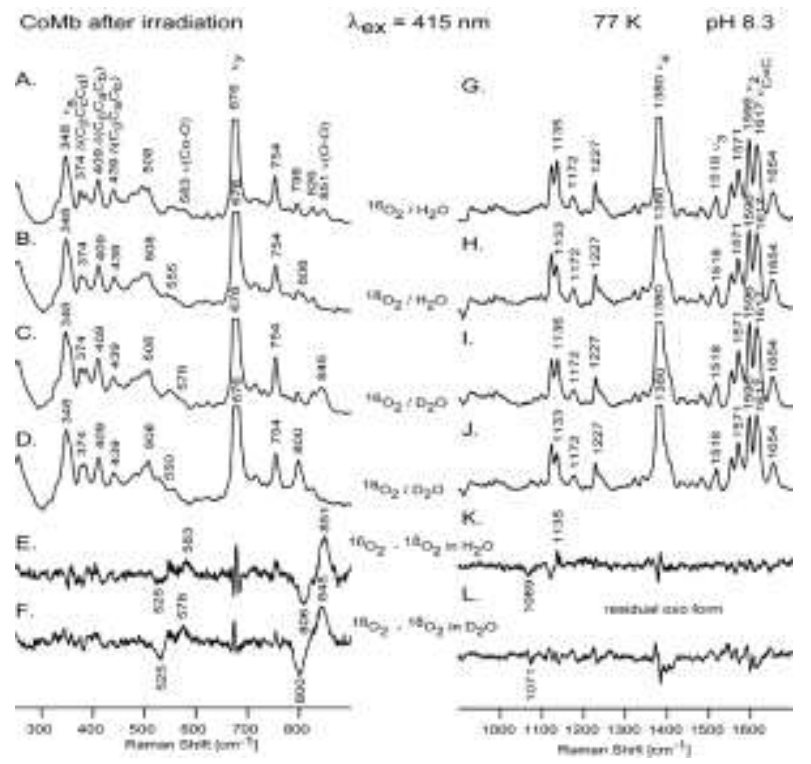

Figure 3 Low and high frequency resonance Raman spectra of ${ }^{16} \mathrm{O}_{2} / \mathrm{H}_{2} \mathrm{O},{ }^{18} \mathrm{O}_{2} / \mathrm{H}_{2} \mathrm{O}$, ${ }^{16} \mathrm{O}_{2} / \mathrm{D}_{2} \mathrm{O}$ and ${ }^{18} \mathrm{O}_{2} / \mathrm{D}_{2} \mathrm{O}$ samples of $\mathrm{Co}(\mathrm{II})$ myoglobin (MbCo) after irradiation and their difference spectra. 
While the $\mathrm{v}(\mathrm{O}-\mathrm{O})$ modes yield the expected isotopic shifts, the difference pattern observed between 583 and $525 \mathrm{~cm}^{-1}$ is complicated by overlap of modes associated with unreduced Co-O-O fragments, the modes for the latter appearing at 549 and $525 \mathrm{~cm}^{-1}$, as documented in Figure 2. Thus, given a $\mathrm{v}\left(\mathrm{Co}^{-16} \mathrm{O}\right)$ appearing at $583 \mathrm{~cm}^{-1}$ for the new hydroperoxo- form, one expects a corresponding $\mathrm{v}\left(\mathrm{Co}^{-18} \mathrm{O}\right)$ at $\sim 555$ $\mathrm{cm}^{-1}$, which is closely overlapped with the $\mathrm{v}\left(\mathrm{Co}^{-16} \mathrm{O}\right)$ mode of the residual non-reduced parent that is seen in Figure 2 at $549 \mathrm{~cm}^{-1}$. This partial cancellation of the 555 and $549 \mathrm{~cm}^{-1}$ features leaves the 583 and $525 \mathrm{~cm}^{-1}$ peaks; i.e., the apparently non-ideal (large) isotopic shift is actually an expected consequence of the presence of residual non-reduced form. This expected cancellation effect indeed also occurs for the samples in deuterated solvent, noting that the observed 578 $\mathrm{cm}^{-1}$ component in the E-F difference trace of Figure 3 is shifted down by $5 \mathrm{~cm}^{-1}$ compared to its value in protonated solvents, whereas its ${ }^{18} \mathrm{O}$ counterpart is again cancelled leaving only the $525 \mathrm{~cm}^{-1}$ remnant from residual ${ }^{18} \mathrm{O}_{2}$-CoMb precursor, which is naturally insensitive to $\mathrm{H} / \mathrm{D}$ effects.

\section{Discussion}

Relatively recent work on $\mathrm{Y}$-irradiated samples of oxygenated globins that employed both EPR and Mossbauer techniques, as well as carefully conducted annealing procedures, have helped define the composition of such cryoreduced samples [32, 33]. There it was found that $\mathrm{y}$-irradiation of oxyMb yields a low-spin ferric peroxo species, which persists up to about $195 \mathrm{~K}$, but then converts to a mixture of mainly peroxo-Mb and hydroperoxoMb; however, the authors of that work did note that the annealing procedure also generates another product considered to be a ferryl heme (i.e., Compound II) [33,34]. In our previous RR studies of cryoreduced oxyMb $[17,18]$, even at lower temperatures ( $77 \mathrm{~K}$ and $145 \mathrm{~K}$ ) we were able to observe only one $\mathrm{v}(\mathrm{Fe}-\mathrm{O})$ mode, which was assigned to the hydroperoxo-form, based on an observed $5 \mathrm{~cm}^{-1}$ down shift in deuterated solvents. This somewhat surprising lack of evidence for the non-protonated peroxo-species was attributed to unintentional annealing of the surface of the sample with the laser beam used to excite the RR spectrum; as was duly noted there [17], subsequent EPR studies of the same tube showed that the bulk of the sample was indeed still in the non-protonated peroxo-

Journal of Inorganic Biochemistry, Vol. 102, No. 10 (October 2008): pg. 1952-1957. DOI. This article is (C Elsevier and permission has been granted for this version to appear in e-Publications@Marquette. Elsevier does not grant permission for this article to be further copied/distributed or hosted elsewhere without the express permission from Elsevier. 
form. The data acquired here for the cryoreduced OxyCoMb samples, exhibiting $\sim 5 \mathrm{~cm}^{-1} \mathrm{H} / \mathrm{D}$ shifts, also confirm the hydroperoxoformulation for these cobalt-substituted myoglobins.

The most important finding in the present work is the confirmation that, while the $\mathrm{v}(\mathrm{O}-\mathrm{O})$ mode of the hydroperoxoderivative of the native iron-containing globin is not resonance enhanced with excitation near the Soret transition, this internal $v(\mathrm{O}-\mathrm{O})$ mode is indeed effectively enhanced in the case of the cobaltsubstituted analogues. While the dioxygen adducts of nearly all histidyl-ligated heme proteins fail to exhibit efficient enhancement of these key modes, it is noted that dioxygen adducts of cytochromes P450 do exhibit strongly enhanced $v(0-0)$ modes; i.e., the native (iron-containing) thioloate-ligated proteins show enhancements similar to the cobalt-substituted, histidyl-ligated heme proteins. These similarities extend to the peroxo- and hydroperoxo derivatives of these proteins. Thus, as was recently shown in our laboratory, in a manner analogous to the cobalt globins studied here, Cytochrome P450 camphor (P450cam) forms a hydroperoxo-derivative whose $\mathrm{v}(\mathrm{O}-\mathrm{O})$ mode is readily observed at $799 \mathrm{~cm}^{-1}$, exhibiting expected isotopic shifts upon both ${ }^{18} \mathrm{O}_{2}$ and $\mathrm{D}_{2} \mathrm{O}$ substitutions [19].

Finally, inasmuch as this is apparently the first report of the preparation and characterization of a hydroperoxo- derivative of a cobalt-substituted heme protein, it is of interest to compare the vibrational behavior of these with the corresponding native myoglobin samples. As has been well documented in many earlier studies comparing the $\mathrm{M}-\mathrm{O}-\mathrm{O}$ fragments of the parent dioxygen adducts of heme proteins and model compounds, the $\mathrm{v}(\mathrm{Co}-\mathrm{O})$ is typically observed to occur at frequencies that are $30-50 \mathrm{~cm}^{-1}$ lower than the corresponding $\mathrm{v}(\mathrm{Fe}-\mathrm{O})$ modes $[12,39,45-48]$. The newly acquired data presented here for the hydroperoxo derivative of CoMb are entirely consistent with this trend, documenting a $34 \mathrm{~cm}^{-1}$ lower frequency for the $\mathrm{v}(\mathrm{Co}-\mathrm{O})$ mode compared with the $617 \mathrm{~cm}^{-1}$ value observed for the native protein; it is also noted that similar differences in $\mathrm{v}(\mathrm{M}-\mathrm{O})$ have been observed [46] and calculated $[49,50]$ in comparing the hydroperoxo forms of cobalt $\left(545 \mathrm{~cm}^{-1}\right)$ and iron $\left(575 \mathrm{~cm}^{-1}\right.$, calculated) bleomycins. A comparison of corresponding $\mathrm{v}(\mathrm{O}-\mathrm{O})$ modes is strictly not possible, given the fact that these are not resonance enhanced for the native systems; the relatively scarce data available

Journal of Inorganic Biochemistry, Vol. 102, No. 10 (October 2008): pg. 1952-1957. DOI. This article is (C Elsevier and permission has been granted for this version to appear in e-Publications@Marquette. Elsevier does not grant permission for this article to be further copied/distributed or hosted elsewhere without the express permission from Elsevier. 
for the parent dioxygen adducts, obtained mainly from IR difference spectroscopy, generally show that this mode is reflective of a bound superoxide formulation and is about $7-10 \mathrm{~cm}^{-1}$ lower for the native systems than for the cobalt-substituted analogues $[47,48]$. Given this difference observed for the parent dioxygen adducts, a reasonable expected value for the $\mathrm{v}(\mathrm{O}-\mathrm{O})$ of the hydroperoxoMb would be near $840 \mathrm{~cm}^{-1}$. While this species has yet to be studied by IR difference spectroscopy, data has been published for several end-on hydroperoxo complexes of ferric model compounds [51], which suggests that for complexes having $\mathrm{v}(\mathrm{Fe}-\mathrm{O})$ modes near $630 \mathrm{~cm}^{-1}$, the corresponding $\mathrm{v}(\mathrm{O}-\mathrm{O})$ modes are seen near $790 \mathrm{~cm}^{-1}$. Inasmuch as these modes are expected to be inversely correlated [52-54], the $617 \mathrm{~cm}^{-1}$ frequency observed for hydroperoxo $\mathrm{Mb}$ would be expected to yield a $\mathrm{v}(\mathrm{O}-\mathrm{O})$ frequency between these 790 and $\sim 850 \mathrm{~cm}^{-1}$ values; i.e., the 617 $\mathrm{cm}^{-1}$ value observed for $\mathrm{v}(\mathrm{Fe}-\mathrm{O})$ is reasonably consistent with an expected value of $\sim 840 \mathrm{~cm}^{-1}$ for the unobserved $\mathrm{v}(\mathrm{O}-\mathrm{O})$.

\section{Acknowledgments}

The authors acknowledge financial assistance from the Pfletschinger Habermann Fund and a Way-Klingler award from Marquette University and for a grant from the National Institutes of Health (DK 35153 to JK). We gratefully appreciate the help provided by Dr. John Bentley, Notre Dame Radiation Laboratory (Notre Dame University, IN), a facility of the U.S. Department of Energy, Office of Basic Energy Science.

\section{Footnotes}

Publisher's Disclaimer: This is a PDF file of an unedited manuscript that has been accepted for publication. As a service to our customers we are providing this early version of the manuscript. The manuscript will undergo copyediting, typesetting, and review of the resulting proof before it is published in its final citable form. Please note that during the production process errors may be discovered which could affect the content, and all legal disclaimers that apply to the journal pertain.

\section{References}

1. Dolphin D, Felton RH. Accts. Chem. Res. $1974 ; 7: 26-32$.

2. Poulos TL, Kraut J. J. Biol. Chem. 1980;255:8199-8205.

3. Dawson JH, Sono M. Chem. Rev. 1987;87:1255-1276.

Journal of Inorganic Biochemistry, Vol. 102, No. 10 (October 2008): pg. 1952-1957. DOI. This article is @ Elsevier and permission has been granted for this version to appear in e-Publications@Marquette. Elsevier does not grant permission for this article to be further copied/distributed or hosted elsewhere without the express permission from Elsevier. 
NOT THE PUBLISHED VERSION; this is the author's final, peer-reviewed manuscript. The published version may be

accessed by following the link in the citation at the bottom of the page.

4. Veitch NC, Smith AT. In: Advances in Inorganic Chemistry. Sykes AG, Mauk G, editors. vol. 51. New York: Academic Press; 2000. pp. 107162.

5. Groves JT, Wang CC-Y. Curr. Opin. Chem. Biol. 2000;4:687-695.

6. Denisov IG, Makris TM, Sligar SG, Schlichting I. Chem. Rev. 2005;105:2253-2277.

7. Shaik S, Hirao H, Kumar D. Accts. Chem. Res. 2007;40:532-542.

8. Kitagawa T, Mizutani Y. Coord. Chem. Rev. 1994;135/136:685-735.

9. Palaniappen V, Terner J. J. Biol. Chem. 1989;264:16046-16053.

10. Hosten CM, Sullivan AM, Palaniappen V, Fitzgerald MM, Terner J. J. Biol. Chem. 1994;269:13966-13978.

11. Kincaid JR, Zheng Y, Al-Mustafa J, Czarnecki K. J. Biol. Chem. $1996 ; 271: 28805-28811$.

12. Kincaid JR. In: The Porphyrin Handbook. Kadish KM, Smith KM, Guilard R, editors. New York: Academic Press; 2000. pp. 225-291.

13. Terner J, Palaniappan V, Gold A, Weiss R, Fitzgerald MM, Sullivan AM, Hosten CM. J. Inorg. Biochem. 2006;100:480-501.

14. Kozlowski PM, Kuta J, Ohta T, Kitagawa T. J. Inorg. Biochem. 2006;100:744-750.

15. Stone KL, Behan RK, Green MT. Proc. Natl. Acad. Sci. U S A. 2006;103:12307-12310.

16. Behan RK, Green MT. J. Inorg. Biochem. 2006;100:448-459.

17. Ibrahim M, Denisov IG, Makris TM, Kincaid JR, Sligar SG. J. Am. Chem. Soc. $2003 ; 125: 13714-13718$.

18. Ibrahim M, Kincaid JR. J. Porphyrins Phthalocyanines. 2004;8:215-225.

19. Mak PJ, Denisov IG, Victoria D, Makris TM, Deng T, Sligar SG, Kincaid JR. J. Am. Chem. Soc. 2007;129:6382-6383. [

20. Symons MCR, Peterson RL. Proc. R. Soc. London, Ser. B. 1978;201:285300.

21. Symons MCR, Peterson RL. Biochim. Biophys. Acta. 1978;525:241-246.

22. Gasyna Z. FEBS Lett. 1979;106:213-218.

23. Kappl R, Hoehn-Berlage M, Huettermann J, Bartlett N, Symons MCR. Biochim. Biophys. Acta. 1985;827:327-343.

24. Davydov RM, Yoshida T, Ikeda-Saito M, Hoffman BM. J. Am. Chem. Soc. $1999 ; 121: 10656-10657$.

25. Davydov RM, Macdonald IDG, Makris TM, Sligar SG, Hoffman BM. J. Am. Chem. Soc. 1999;121:10654-10655.

26. Davydov RM, Makris TM, Kofman V, Werst DE, Sligar SG, Hoffman BM. J. Am. Chem. Soc. 2001;123:1403-1415.

27. Davydov RM, Ledbetter-Rogers A, Martasek P, Larukhin M, Sono M, Dawson JH, Masters BS, Hoffman BM. Biochemistry. 2002;41:1037510381.

Journal of Inorganic Biochemistry, Vol. 102, No. 10 (October 2008): pg. 1952-1957. DOI. This article is (C) Elsevier and permission has been granted for this version to appear in e-Publications@Marquette. Elsevier does not grant permission for this article to be further copied/distributed or hosted elsewhere without the express permission from Elsevier. 
NOT THE PUBLISHED VERSION; this is the author's final, peer-reviewed manuscript. The published version may be

accessed by following the link in the citation at the bottom of the page.

28. Davydov RM, Kofman V, Fujii H, Yoshida T, Ikeda-Saito M, Hoffman BM. J. Am. Chem. Soc. 2002;124:1798-1808.

29. Jin S, Makris TM, Bryson TA, Sligar SG, Dawson JH. J. Am. Chem. Soc. 2003; 125:3406-3407.

30. Davydov RM, Perera R, Jin S, Yang TC, Bryson TA, Sono M, Dawson JH, Hoffman BM. J. Am. Chem. Soc. 2005;127:1403-1413.

31. Kim SH, Yang T-C, Perera R, Jin S, Bryson TA, Sono M, Davydov RM, Dawson JH, Hoffman BM. Dalton Trans. 2005:3464-3469.

32. Davydov RM, Kofman V, Nocek JM, Noble RW, Hui H, Hoffman BM. Biochemistry. 2004;43:6330-6338.

33. Garcia-Serres R, Davydov RM, Matsui T, Ikeda-Saito M, Hoffman BM, Huynh BH. J. Am. Chem. Soc. 2007;129:1402-1412.

34. Davydov RM, Osborne RL, Kim SH, Dawson JH, Hoffman BM. Biochemistry. 2008;47:5147-5155.

35. Bangcharoenpaurpong O, Rizos AK, Champion PM, Jollie D, Sligar SG. J. Biol. Chem. 1986;261:8089-8092.

36. Hu S, Schneider AJ, Kincaid JR. J. Am. Chem. Soc. 1991;113:4815-4822.

37. MacDonald IDG, Sligar SG, Christian JF, Unno M, Champion PM. J. Am. Chem. Soc. 1999;121:376-380.

38. Das TK, Couture M, Ouellet Y, Guertin M, Rousseau DL. Proc. Natl. Acad. Sci. U S A. 2001;98:479-484.

39. Bruha A, Kincaid JR. J. Am. Chem. Soc. 1988;110:6006-6014.

40. Ascoli F, Rosaria M, Fanelli R, Antonini E. In: Methods in Enzymology. Sauer K, editor. vol. 76. New York: Academic Press; 1981. pp. 72-87.

41. Yonetani T, Yamamoto H, Woodrow GV., III J. Biol. Chem. 1974;249:682-690.

42. Shriver DF, Dunn JBR. Appl. Spectrosc. 1974;28:319-323.

43. Proniewicz LM, Kincaid JR. J. Am. Chem. Soc. 1990;112:675-681.

44. Veas C, McHale JL. J. Am. Chem. Soc. 1989;111:7042-7046.

45. Yu N-T, Kerr EA. In: Biological Application of Raman Spectroscopy. Spiro TG, editor. vol. 3. New York: John Wiley \& Sons; 1988. pp. 39-95.

46. Rajani C, Kincaid JR, Petering DH. J. Am. Chem. Soc. 2004;126:38293836.

47. Miller LM, Chance MR. Bichemistry. 1995;34:10170-10179.

48. Potter WT, Tucker MP, Houtchens RA, Caughey WS. Biochemistry. 1987;26:4699-4707.

49. Kozlowski PM, Nazarenko VV, Jarzecki AA. Inorg. Chem. 2006;45:14241426.

50. Lehnert N, Neese F, Ho RYN, Que L, Jr, Solomon EI. J. Am. Chem. Soc. $2002 ; 124: 10810-10822$.

51. Ho RYN, Roelfes G, Feringa BL, Que L., Jr J. Am. Chem. Soc. $1999 ; 121: 264-265$.

Journal of Inorganic Biochemistry, Vol. 102, No. 10 (October 2008): pg. 1952-1957. DOI. This article is (C Elsevier and permission has been granted for this version to appear in e-Publications@Marquette. Elsevier does not grant permission for this article to be further copied/distributed or hosted elsewhere without the express permission from Elsevier. 
NOT THE PUBLISHED VERSION; this is the author's final, peer-reviewed manuscript. The published version may be accessed by following the link in the citation at the bottom of the page.

52. Denisov IG, Mak PJ, Makris TM, 1, Sligar SG, Kincaid JR. J. Phys. Chem. 2008 (in press)

53. Shaik S, Kumar D, de Visser SP, Altun A, Thiel W. Chem. Rev. 2005;105:2279-2328.

54. Unno M, Chen H, Kusama S, Shaik S, Ikeda-Saito M. J. Am. Chem. Soc. 2007;129:13394-13395.

\section{About the Authors}

Corresponding author: James R. Kincaid, Tel.: +1 414288 3539; fax: +1 414 288 7066. E-mail address: james.kincaid@mu.edu (J.R. Kincaid). 